\title{
Proximate chemical composition of sea grapes Caulerpa racemosa (J. Agardh, 1873) collected from a sub-tropical coast
}

\begin{abstract}
Background: Nutritional fact study has prime importance to make the species edible and commercially viable to the consumers. Proximate chemical composition and amino acid profile were investigated to understand the nutritional value and protein quality of an edible algae Caulerpa racemosa. Methods: Samples were collected randomly by hand from the intertidal zone of the sub-tropical coastal Island St. Martin's Island from February 2013 to May 2014. Samples were preserved using standard methods for chemical analysis. Proximate composition was determined using standard methods, Kjeldahl method for protein, Soxhlet method for crude lipid, $\mathrm{H} 2 \mathrm{SO} 4(0.3 \mathrm{~N})$ and $\mathrm{NaOH}(0.5 \mathrm{~N})$ for dietary fibre, muffle furnace method for moisture content, ion-exchange chromatography for amino acid and statistical package used for validating the data. Results: The result of the study reveals that $\mathrm{C}$. racemosa contains higher amount of proteins $(19.72 \pm 0.77 \%)$, crude lipid $(7.65 \pm 1.19 \%)$ and fibre $(11.51 \pm 1.32 \%)$ compared to other green and brown algae. The higher concentration of aspartic acid $(12.7 \pm 0.2 \%)$ and glutamic acid $(9.2 \pm 0.7 \%)$ were observed in C. racemosa, while histidine $(2.6 \pm 0.7 \%)$, methionine $(1.4 \pm 0.4 \%)$ and tyrosine $(3.8 \pm 0.2 \%)$ were the limiting amino acids. Lysine $(6.6 \pm 0.2 \%)$, leusine $(6.9 \pm 0.6 \%)$, glycine $(6.5 \pm 0.4 \%)$, arginine $(6.4 \pm 0.3 \%)$, alanine $(7.6 \pm 0.6 \%)$ and threonine $(6.2 \pm 0.5 \%)$ were obtained at a higher percentage of total amino acids. Conclusion: This study suggests that $\mathrm{C}$. racemosa could be potentially used as a nutritious and functional food item for human consumption. Further studies on this edible species should be focused on fatty acid composition, vitamins, nonstarch polysaccharide constituents, trace elements and sensory perceptions in order to depict safer and versatile utilization.
\end{abstract}

Keyword: Caulerpa racemosa; Green seaweed; Proximate chemical composition 